\title{
PEMECAHAN MASALAH SPASIAL MATEMATIS CALON GURU MATEMATIKA DITINJAU DARI LANGKAH-LANGKAH PEMECAHAN MASALAH POLYA
}

\author{
Fiki Alghadari \\ fiki_alghadari@stkipkusumanegara.ac.id \\ STKIP Kusuma Negara Jakarta
}

\begin{abstract}
This study aimed to find out the constraints faced by a subject of study in solving spatial problems by applying the general steps of Polya problem solving. The object of study was written answers of completion tests about spatial mathematical problem solving ability created by the subject. Subjects of this study were three students on academic year 2015 / 2016. The data collection used qualitative approach. Analysis is focused on some writing answers by the subject. The weakness of the subject on the spatial problem-solving abilities was seen in error imagination which formed a mental image and imagines the spatial image in visual thinking, so that the subject of women failed to make the spatial transformation correctly. This failure is a problem on spatial visualization ability and would also impact to the failure of solving spatial problems. The results of the inconsistent analysis was found between the analysis of the first test and second, because the quality of the test were different spatially.
\end{abstract}

Keywords: spatial problem solving

\begin{abstract}
ABSTRAK
Studi ini dilakukan untuk mengetahui kendala yang dihadapi subjek studi dalam menyelesaikan masalah spasial dengan mengaplikasikan langkah-langkah umum pemecahan masalah dari Polya. Objek studi yaitutulisan jawaban penyelesaian tes kemampuan pemecahan masalah spasial matematis yang dibuat oleh subjek. Subjek studi ini adalah tiga orangmahasiswa tahun pelajaran 2015/2016.Pengumpulan data menggunakan pendekatan kualitatif. Analisisdifokuskan pada beberapa tulisan jawaban oleh subjek. Kelemahan subjek pada kemampuan pemecahan masalah spasial terlihat pada kekeliruanberimajinasi membentuk mental image membayangkanspatial imageryatau visual imagerydalam pemikirannya,sehingga subjek perempuan gagal membuat transformasi spasialdengan benar. Kegagalan ini merupakan masalah padakemampuan visualisasi spasialdan akan berdampak pula pada gagalnya memecahkan masalah spasial. Hasil analisis yang tidak konsisten ditemukan antara analisis tes pertama dan yang kedua, karena kualitas tes memang berbeda secara spasial.
\end{abstract}

Kata kunci: pemecahan masalah spasial.

\section{PENDAHULUAN}

Kesulitan memahami konsep matematis telah menjadi masalah klasik. Penyebabnya tidak lepas dari ketidakmampuan menemukan kaitan setiap konsep. Minimnya pengetahuan awal sebagai fondasi utama untuk menambah ide matematis baru, kurang jam terbang dalam memecahkan masalah. Akibatnya koneksi pengetahuan awal dengan informasi baru tidak terjalin sempurna, sehingga kesulitan belajar mempengaruhi kemampuan memformulasi, merepresentasi, dan memecahkan masalah (Steedly, et al., 2008).

Pentingnya pemecahan masalah karena merupakan standar proses yang termuat dalam NCTM. Memecahkan masalah bukan hanya sebuah tujuan belajar matematika, tetapi juga bagian utama pada proses pencapaiannya. Pemecahan masalah merupakan pembelajaran konsep berdasarkan fakta-fakta dengan menghubungkan objek-objek ke dalam aplikasi matematika. Konsep yang dihubungkan dari objek-objek matematis merupakan strategi yang digunakan dalam menemukan penyelesaian pemecahan masalah (NCTM, 2000).

Pemecahan masalah adalah tujuan yang harus dicapai, dan bukan hanya sekadar suatu cara mencapai tujuan. Lebih daripada itu, pemecahan masalah merupakan suatu teknis atau langkah praktis yang mungkinmembantu menyelesaian masalah. Pemecahan masalah dapat juga dipandang sebagai suatu kendaraan yang 
mengantarkan seseorang untuk menyadari indahnya matematika, sekaligus berperan untuk mengikat pengalaman matematika dengan kebermaknaan matematika yang dipelajarinya.

Pemecahan masalah merupakan fokus utama dalam pendidikan matematika untuk meningkatkan kompetensi dan kecakapan pada domain kognitif. Suherman dkk, (2001) menyebutkan bahwa pemecahan masalah merupakan bagian kurikulum matematika yang sangat penting karena dalam proses pembelajaran maupun penyelesaiannyasetiap subjek dimungkinkan memperoleh pengalaman menggunakan pengetahuan serta keterampilan yang sudah dimiliki untuk diterapkan pada pemecahan masalah yang bersifat tidak rutin.

Jadi dalam pemecahan masalah, setiap subjek biasanya berpikir dengan melihat kembali masalah terdahulu untuk menemukan proses solusi yang bisa digunakan dalam masalah yang sedang dihadapi. Dengan kata lain, pengetahuan awal dan pemahaman akan menjadi landasan berpikir atau sebagai pijakan utama yang saling bersimbiosis dengan pemecahan masalah.

Spesifikasi dari kemampuan pemecahan masalah dalam studi ini, akan mengulas tentang kemampuan pemecahan masalah spasial. Kemampuan spasial termasuk dalam salah satu dari sembilan kecerdasan. Setiap subjek memiliki tingkat kecerdasan dan keunikan masing-masing yang merupakan bagian potensinya. Memaksimalkan potensial diri sangat layak untuk diberdayakan, sehingga upaya untuk mengoptimalkan potensial diri seperti kemampuan spasial akan menjadikan suatu bagian utama pada pemilihan studi tingkat lanjut(Pohl dan Lehmann, 2002).

Berkaitan dengan masalah spasial, beberapa hasil studi seperti oleh Sipus dan Cizmesija (2012) menunjukkan bahwa kemampuan representasi dalam ruang berdimensi pada subjek perempuan terlihat lebih rendah. Hasil penelitian tersebut menyebutkan bahwa kemampuan spasial laki-laki lebih baik dari pada perempuan. Hasil riset yang sama juga ditemukan oleh Pohl dan Lehmann (2002). Namun Manger dan Eikeland (Turgut dan Yilmaz, 2012) menemukan bahwa tidak ada perbedaan kemampuan spasial yang signifikan antara laki-laki dan perempuan. Perbedaan kemampuan spasial antara laki-laki dan perempuan memang sangat menarik perhatian, karena banyak hasil penelitian yang saling bertentangan (Yilmaz, 2009; Pohl dan Lehmann, 2002).

Merujuk dari beberapa hasil studi dan pertentangannya di atas, perlu diketahui suatu penyebab yang akan menjadi pokok penting dalam pembahasan untuk selanjutnya dicarikan suatu solusi demi meningkatkan kemampuan pemecahan masalah spasial yang diharapkan.

\section{KAJIAN TEORI}

\section{Kemampuan Pemecahan Masalah Spasial}

Kemampuan pemecahan masalah spasial merupakan kemampuan dalam menemukan suatu pemecahan masalah yang konteks masalahnya mengenai spasial atau keruangan, sehingga antara kemampuan pemecahan masalah dan kemampuan spasial erat kaitannya (Unal, et al., 2009; Guven dan Kosa, 2008; Geary, et al., 2000; Turgut dan Y1lmaz, 2012). Karena adanya keterkaitan kedua kemampuan tersebut, maka dalam studi inidibentuk suatu kemampuan yang lebih spesifik, yaitu kemampuan pemecahan masalah spasial. Keterkaitan antara kedua kemampuan ini terlihat dari definisi oleh para ahli sebagai berikut.

Tokoh pemecahan masalah dari area matematika, Polya mengidentifikasi langkah-langkah umum pemecahan masalah matematis yang harus dilakukan oleh setiap orang untuk memecahkan masalah. Langkah umum pertama yaitu dengan memahami masalah tersebut, kemudian mengembangkan suatu rencana pemecahan 
masalah, mengoperasionalkan rencana yang telah dikembangkan tersebut, dan sampai pada langkah terakhir yaitu mengkaji ulang jawaban dan prosesnya (Sumarmo, 2013).

Kemampuan pemecahan masalah ditandai dengan beberapa indikator yang dijadikan standar kriteria. Kegiatan pemecahan masalah diantaranya meliputi: (1) mengidentifikasi kecukupan data untuk memecahkan masalah; (2) membuat model matematis dari suatu masalah dan menyelesaikannya; (3) memilih dan menerapkan strategi untuk menyelesaikan masalah; (4) menginterpretasikan hasil dan memeriksa kebenarannya; (5) menerapkan matematika secara bermakna (Sumarmo, 2013; Shadiq, 2004; Shadiq, 2009 ).

$\begin{array}{ccr}\text { Sedangkan Linn dan } & \text { Petersen } \\ \text { mendefinisikan } & \text { kemampuan } & \text { spasial }\end{array}$
adalah kemampuan merepresentasi, mentransformasi, menggenerasi, menggunakan simbolis, informasi yang tidak disebutkan (Yilmaz, 2009; Sipus dan Cizmesija 2012). Kemampuan spasial sangat penting untuk pemahaman geometris dan memiliki hubungan yang positif terhadap pemecahan masalah (Unal, et al., 2009; Guven dan Kosa, 2008; Geary, et al., 2000).

Kemampuanspasial adalah kemampuan interpretasi visual kualitas tinggi, karena setiap subjek membangun pengetahuan dan pemahamannya dalam bentuk mental image untuk merepresentsikan hubungan spasial antara bagian pada objek dan lokasi objek tersebut dalam ruangan (Hegarty dan Kozhevnikov, 1999; Turgut dan Yilmaz, 2012). Sehingga, Linn dan Petersen (Yilmaz, 2009) mengindikasikan bahwa kemampuan spasial bukan terbentuk dari suatu kemampuan, melainkan kombinasi seperti kemampuan memecahkan pertanyaan geometri, kemampuan penggunaan peta, dan kemampuan representasi dalam ruang berdimensi.

Kombinasi tidak sempurna dari beberapa kemampuan tersebut memungkinkan sebagai penyebab utama rendahnya kemampuan representasi dalam ruang berdimensi oleh subjek perempuan. Disarankan untuk topik spasial geometri agar dihubungkan dengan situasi dan objek kehidupan nyata, atau saran lain yaitu adalah menghubungkan dengan area kurikulum lain (Sipus dan Cizmesija, 2012).

Berdasarkan beberapa pendapat dari para ahlidi atas,terlihat bahwapada indikator kemampuan pemecahan masalah yaitumembuat model atau representasi matematis dari suatu masalah dan menyelesaikannya, sangat erat kaitannya dengan definisi kemampuan spasial yaitu kemampuan merepresentasi. Sehingga, keterkaitan ini bisa dijadikan sebagai indikator pada kemampuan pemecahan masalah spasial.

Dalam hal ini, terlebih dahulu subjekakan menggunakan kemampuan spasialnya dan kemudian bisa memecahkan masalah tersebut, sehingga subjek yang mengalami kesulitan dalam masalah spasial sudah pasti tidak mampu menyelesaikan masalah hingga tahap akhir.

\section{METODE}

Subjek studi ini adalah beberapa mahasiswa tahun pelajaran 2015/2016 dengan menggunakan metode pendekatan kualitatif. Untuk mengetahui tingkat kemampuan pemecahan masalah spasial, diberikan instrument tes berbentuk uraian, yaitu bentuk tes kemampuan pemecahan masalah seperti contoh berikut.

1. Diketahui kubus ABCD. EFGH dengan panjang rusuk $a \mathrm{~cm}$. Jarak garis BD ke bidang AFH adalah ....

2. Prismasegilima tegak ABCDE FGHIJ, $\mathrm{P}$ pada rusuk EJ dan $\mathrm{Q}$ pada rusuk $\mathrm{BC}$. Lukis titik tembus garis PQ pada bidang ADIF. 


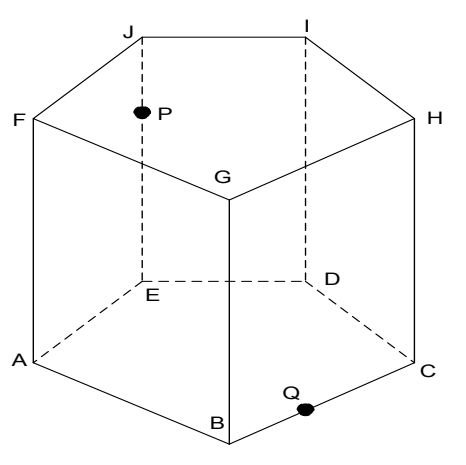

Gambar 1

Prisma Segilima

Jawaban subjek dari pertanyaan di atas akan dijadikan data kualitatif sebagai sumber yang akan dianalisis dandieksplorasi untuk mengetahui secara mendalam terhadap suatu permasalahan pada subjek.

\section{HASIL DAN PEMBAHASAN}

Hasil studi akan difokuskan pada tulisan jawaban yang dibuat oleh subjek.Jawaban tes kemampuan pemecahan masalah spasial oleh subjek memiliki suatu kesamaan pada langkah umum pemecahan masalah, berikut ini sebagian tampilanpemecahan masalah spasial untuk tes nomor 1, dari beberapa subjek.

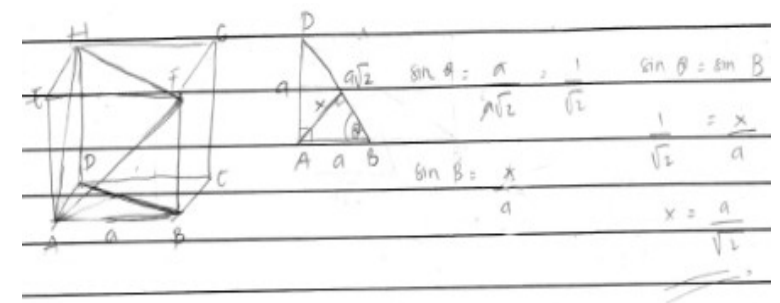

Gambar 2

Penyelesaian subjek perempuan

Berikut ini adalah dinamika operasional pemecahan masalah yang dibuatnya. Pada gambar 2, terlihat bahwa subjek tersebut mampu memahami masalah. Memahami masalah merupakan usaha awal untuk menemukan pemecahan, karena termasuk dalam salah satu langkah-langkah yang dikemukakan Polya, yaitu memahami masalah (Sumarmo, 2013).

Langkah berikutnya yaitu mengembangkan suatu rencana pemecahan masalah. Langkah kedua ini juga tampak pada gambar
2, yaitu subjek menghubungkan suatu titik sudut kubus ke titiksudutyang lain yang diberikan pada tes, sehingga terbentuk suatu bidang segitiga dan suatu garis.Kelemahan kemampuan spasial terlihat ketika subjek berusaha menemukan jarak antara titik dan bidang,subjek gagal menemukan jarak yang dimaksudkan pada tes.

Beberapa indikator pemecahan masalah telah dipenuhi oleh subjek, diantaranya adalah mengidentifikasi kecukupan data untuk memecahkan masalah, memilih dan menerapkan strategi untuk menyelesaikan masalah, dan membuat model matematis dari suatu masalah.Model matematis yang dibuat untuk memecahkan masalah dinamakanjuga dengan representasi matematis. Representasi matematis merupakan suatu bentuk pengganti yang memuat informasi abstrak.

Representasi matematis yang dibuat oleh subjek terlihat pada segitiga ABD pada gambar 2.Representasi semacam ini dinamakan dengan transformasi spasial(Ehrlich, et al., 2006).Transformasi spasial merupakan output visualisasi spasial (Yilmaz, 2009; Turgut dan Y1lmaz, 2012; Unal, et al., 2009). Transformasi spasial merupakanhasil imajinasiyang divisualkan. Transformasi spasial adalah bentukperumpamaan spasial (spatial imagery)dalam pemikiran (Garderen, 2006). Artinya, suatu objek dalam ruang dimensi ditransformasikan menjadi suatu bentuk objek representasi didimensi bidang datar, atau mentransformasikan suatu bentuk objek yang awalnya dimuat dalam tiga dimensi menjadisuatu representasi pada dua dimensi. Berdasarkan segitiga tersebut, maka terlihat bahwa subjek mengoperasikanrencana yang dikembangkannya.

Transformasi spasial yang dibuat oleh subjekbelum tepat, karena subjek melihat garis sebagai acuan untuk menentukan jarak antara garis dengan bidang, sehingga subjek lansung menentukan segitiga ABD sebagai objek yang dijadikan bentuk transformasi spasial pada dua dimensi. Subjek melupakan 
definisi bahwa jarak antara garis dan bidang merupakan jarak terdekat diantara keduanya. Selain itu, memungkinkantidak terpikirkanjuga oleh subjek bahwa bidang yang miring akan menggeser titik tumpu untuk menentukan jarak antara garis dan bidang.

Temuan yang serupa juga terlihat pada gambar 3. Bahkan segitiga DHO yang dibuat subjek sama sekali tidak ada kaitannya dengan langkah untuk menghitung jarak dari garis ke bidang, sehingga kelemahan pada kemampuan spasial sangat jelas terlihat. Pada temuan ini, subjek hanya sampai pada tahap kedua dalam langkah umum peneyelesaian masalah, yaitu mengembangkan suatu rencana pemecahan masalah.

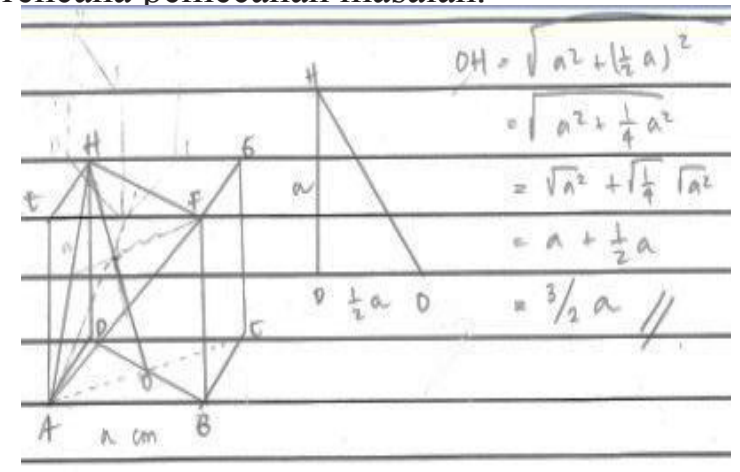

Gambar 3

Penyelesaian subjek perempuan

Subjek gagal menemukan jarak yang dimaksudkan, sehingga subjek gagal memecahkan masalah. Hal ini bersesuaian dengan suatu pendapat bahwa kemampuan spasial sangat penting untuk pemahaman geometris dan memiliki hubungan yang positif terhadap pemecahan masalah (Unal, et al., 2009; Guven dan Kosa, 2008; Geary, et al., 2000; Turgut dan Y1lmaz, 2012).Lebih lanjut, Hegarty dan Kozhevnikov (1999) menyatakan bahwa representasi spasial dapat dijadikan suatu klasifikasi andalanuntuk sukses memecahkan masalah. Dengan kata lain, subjek gagal merepresentasi jarak yang dimaksud pertanyaan, sehingga kemampuan spasial tidak terkombinasi dengan baik, maka subjek gagal memecahkan masalah.

Dalam usaha memecahkan masalah spasial yang dilakukan oleh subjek, telah mencakup beberapa kemampuan matematis yang diperlukan.Diantaranya yang lain yang telah terlihat pada temuan di atas adalah kemampuan pemahaman dan kemampuan representasi matematis. Sehingga sesuai dengan indikasi yang dikemukakan Linn dan Petersen (Yilmaz, 2009) bahwa kemampuan spasial bukan terbentuk dari suatu kemampuan melainkan kombinasi dari beberapa kemampuan.

Sedikit berbeda terlihat pada pemecahan masalaholeh subjeklain, yaitu sebagaiberikut.

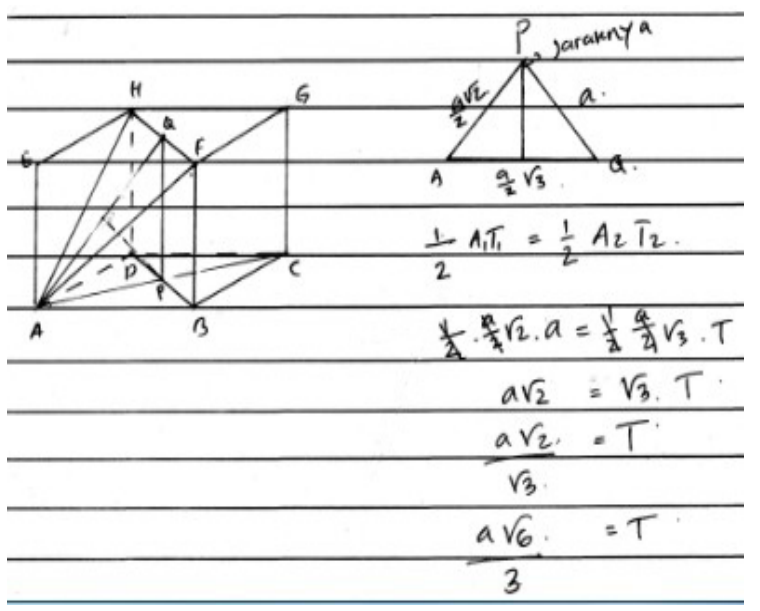

Gambar 4

Penyelesaian subjek laki-laki

Subjek ini mampu memahami dan menemukan jarak yang dimaksud oleh pertanyaan. Perbedaan terlihat jelas pada kualitas kemampuan spasial antara subjek penulis gambar 2, gambar 3, dan gambar 4. Pada gambar 4 terlihat bahwa subjek memiliki kemampuan perumpamaan visual (visual imagery) (Garderen, 2006), ataumembuat gambaran mental (mental image) (Sipus dan Cizmesija, 2012) pada kategori yang baik. Clements mendefinisikan visual imagery merupakan kemampuan membuat suatu gambar dalam pemikiran, sedangkan Presmeg mendefinisikan visual imagery merupakan skema mental yang menggambarkan informasi visual atau spasial (Garderen, 2006). Dengan visual imagery, subjek tersebut mampu membayangkan suatu bidang dan suatu garis yang ada dalam ruang, dan pada akhirnya menemukan jarak yang 
dimaksud oleh pertanyaan.Kemudian subjek juga mampu melakukan transformasi spasial dan membuat representasi pada bidang dua dimensi.

Representasi pada bidang dua dimensi terlihat pada segitiga APQ yang dibuat subjek, merupakan hasil dari perumpamaan visual atau gambaran mental yang mewakili bidang AFH dan garis $\mathrm{BD}$, yang dimaksutkan oleh pertanyaan. Sisi AQ merupakan proyeksi bidang AFH pada bidang ACGE, dan titik sudut $\mathrm{P}$ merupakan proyeksi garis $\mathrm{BD}$ pada bidang ACGE. Berdasarkan segitiga APQ pada gambar 3, kesalahan dimuat dalam perhitungan panjang AQ. Tidak ada tulisan yang dibuat untuk perhitungan panjang AQ. Dikarenakan subjek memuat kesalahan dalam mengkalkulasi panjang AQ,makapemecahan masalah oleh subjek belum sampai pada tahap sempurna.

Berdasarkan beberapa temuan pada hasil pemecahan tes nomor 1, serta membandingkan antara kemampuan subjek berdasarkan gender, makatemuan ini bisa dikatakan konsisten dengan hasil temuan sebelumnya bahwa kemampuan representasi dalam ruang berdimensi pada subjek perempuan terlihat lebih rendah (Sipus dan Cizmesija 2012; Pohl dan Lehmann, 2002; Ehrlich, et al., 2006).

Berikut ini sebagian tampilan pemecahan masalah spasial untuk tes nomor 2, dari beberapa subjek.

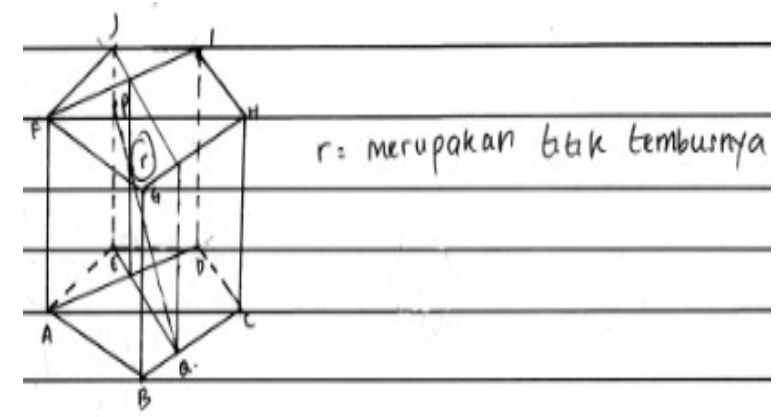

Gambar 5

Penyelesaian subjek laki-laki

Berikut dinamika operasional pemecahan masalah yang dibuat subjek. Pertama-tama subjek memahami masalah. Dilihat dari hasil yang dibuat, subjek sangat memahami masalah. Langkah-langkah yang dilakukan subjek untuk menemukan titik tembus garis PQ pada bidang ADIF terlihat jelas pada penyelesaiannya, yaitu dengan membuat bidang ADIF dan bidang yang memuat garis PQ (bidang JEQQ'). Perpotongan antara kedua bidang ADIF dan bidang JEQQ' membentuk suatu garis potong bidang, yang kemudian berpotongan dengan garis $\mathrm{PQ}$, sehingga perpotongan antara garis potong kedua bidang dengan garis PQ merupakan titik tembusnya.

Semua langkah yang dibuat oleh subjek bersesuaian dengan langkah umum pemecahan masalah. Menggunakan langkahlangkah yang sama juga diperlihatkan oleh subjek lain seperti gambar berikut.

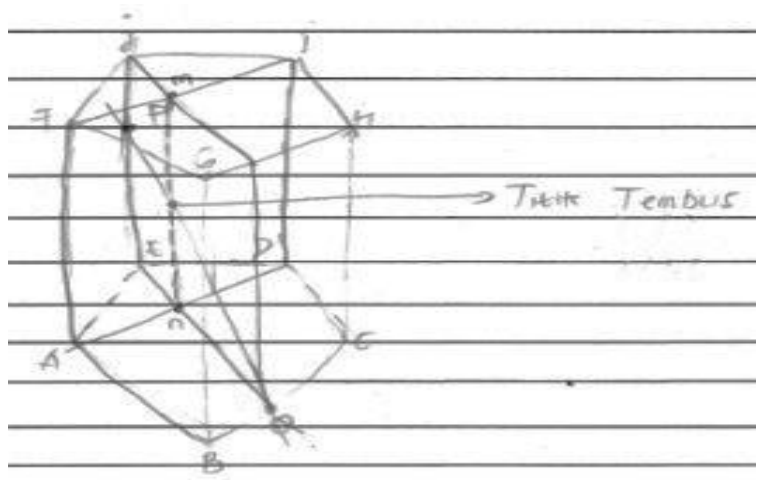

Gambar 6

Penyelesaian subjek perempuan

Subjek tersebut mampu menemukan titik tembus garis PQ dengan bidang ADIF. Namun, terlihat kelemahan pada kemampuan spasial subjek yang lain seperti pada gambar berikut.

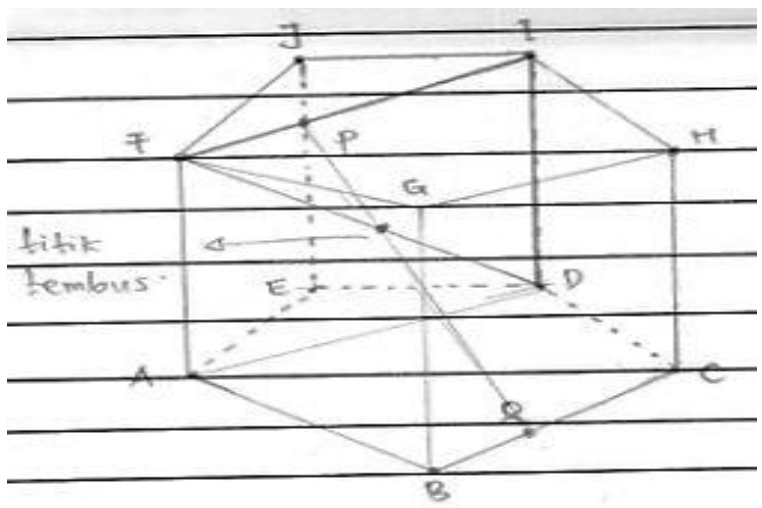

Gambar 7

Penyelesaian subjek perempuan 
Berdasarkan beberapa temuan pada hasil pemecahan tes nomor 2, serta membandingkan antara kemampuan subjek berdasarkan gender, dan dengan alasan karena subjek perempuan mampu memecahkan masalah yang sama dengan subjek laki-laki, maka secara umum temuan ini bisa dikatakan konsisten dengan hasil temuan Manger dan Eikeland (Turgut dan Y1lmaz, 2012) menemukan bahwa tidak ada perbedaan kemampuan spasial yang signifikan antara laki-laki dan perempuan.

Konsistensi yang berbeda dari hasil analisis kemampuan pemecahan masalah spasial matematis tes nomor yang pertama dan nomor yang kedua sesuai dengan pernyataan bahwa banyak hasil penelitian masalah spasial yang saling bertentangan, sehingga kemampuan spasial antara laki-laki dan perempuan sangat menarik perhatikan (Yilmaz, 2009; Pohl dan Lehmann, 2002). Tidak heran apabila ditemukan hasil analisis yang tidak konsisten antara satu sama lain. Namun, apabila ditinjau dari kualitas tes antara yang pertama dengan yang kedua memang memiliki perbedaan kualitas secara spasial.

Montague, et al., (Gardener, 2006) menemukan bahwa rata-rata pencapaian subjek studinya memiliki perbedaan signifikan dalam kualitas representasi masalah.Hasil studi tersebut menunjukan bahwa kualitas representasi masalah memegang peran penting dalam pencapaian. Dengan kata lain, jika kualitas masalah spasial berbeda, maka levelkemampuan spasial yang akan digunakan subjek juga berbeda, selanjutnya jika level kemampuan spasial yang akan digunakan subjek berbeda, maka kualitas representasi masalah yang dibuat siswa juga pasti berbeda. Singkat kata, jika kualitas masalah spasial berbeda, maka kualitas representasi masalah yang dibuat siswa untuk memecahkan masalah juga berbeda.

Perbedaan kualitas masalah spasial yang diajukan pada tes jugaakan mampu diselesaikan dengan baik oleh subjek apabila banyak melakukan latihan spasial.Battista, et al., (Unal, et al., 2009) menemukan bahwa peningkatan kemampuan spasial secara signifikan bagi subjek yang berlatih spasial dari pada yang tidak berlatih. Adapun latihan spasial yang bisa dimanfaatkan untuk meningkatkan kemampuan spasial yaitu seperti melipat-lipat kertas.

Dalam memecahkan masalah spasial, sangat jelas bahwa kemampuan spasial digunakan terlebih dahulu dari pada kemampuan pemecahan masalah. Sudah pasti setiap subjek akan mengalami kesulitan memecahkan masalah apabila kemampuan spasialnya kurang baik. Sebagai contoh terlihat pada kemampuan subjek pada gambar 2, gambar 3, dan gambar 7.Hal ini sesuai dengan pernyataan bahwa kemampuan spasial sangat penting untuk pemahaman geometris dan memiliki hubungan yang positif terhadap pemecahan masalah (Unal, et al., 2009; Guven dan Kosa, 2008; Geary, et al., 2000; Turgut dan Y1lmaz, 2012).

Lebih lanjut, Brown dan Wheatley (Unal, et al., 2009) dalam studinya menemukan bahwa subjek dengan kemampuan spasial yang tinggi atau di atas rata-rata standar tes visualisasi spasial memiliki pemahaman ide matematis tingkat lanjutan, serta mampu bernalar dengan baik, dan memecahkan masalah matematis nonrutin dengan kreatif.

\section{SIMPULAN}

Analisis tes yang pertama diperoleh hasil kemampuan pemecahan masalah spasial subjek perempuan lebih rendah dari pada subjek laki-laki. Sedangkan analisis tes kedua diperoleh hasil kemampuan pemecahan masalah spasial subjek perempuan tidak ada perbedaan yang signifikan dengan kemampuan subjek laki-laki. Artinya, Analisis tulisan jawaban subjek menunjukan bahwa ditemukan tidak konsisten antara analisis tes pertama dan yang kedua. Sebab tidak konsisten ini dikarenakan kualitas tes memang berbeda secara spasial, tes pertama 
lebih sulit karena membutuhkan tingkat kemampuan spasial yang lebih dari pada kemampuan spasial tes kedua.

Meningkatkan kemampuan pemecahan masalah spasial harus terlebih dahulu berupaya untuk meningkatkan kemampuan spasial, karena kedua kemampuan ini saling berkaitan erat dan hubungannya saling membutuhkan satu sama lain.Salah satu bukti otentik mengenai keterkaitan kedua kemampuan ini terlihat pada kelemahan subjek pada kemampuan pemecahan masalah spasial terlihat pada kekeliruanberimajinasi membentuk mental image membayangkan spatial imagery atau visual imagery dalam pemikirannya.

Kekeliruan subjek berimajinasi merupakan kelemahan yang mengakibatkan kegagalan subjek membuat transformasi spasial, sehingga bermasalah padakemampuan visualisasi spasial. Kemampuan visualisasi spasial merupakan salah satu indikator kemampuan spasial, sehingga kemampuan spasial yang kurang baikakan berdampak pada gagalnya memecahkan masalah spasial.

Untuk meningkatkan kemampuan spasial bisa dilakukan dengan latihan seperti melipatlipat kertas. Meningkatnya kemampuan spasial akan meningkatkan kemampuan pemahaman, penalaran, pemecahan masalah, dan berpikir kreatif.

Untuk studi lanjutan mengenai kemampuan pemecahan masalah spasial, disarankan untuk menemukan suatu pendekatan pembelajaran yang mampu menanggulangi kelemahan pada kemampuan spasial subjek sehingga pencapaian akademiknya lebih baik. Kemudian, dengan melihat berbagai jenis gaya belajardan juga untuk memaksimalkan potensi yang dimiliki subjek, lebih baik lagi apabilamampu menemukan implementasipembelajaran yang bisa menghimpun potensi diri dan gaya belajar masing-masing subjek untuk meningkatkan kemampuan spasial matematis siswa.

\section{DAFTAR RUJUKAN}

Ehrlich, S.B., et al. 2006. The Importance of Gesture in Children's Spatial Reasoning. Dalam Developmental Psychology. No. 6. Vol. XLII, 1259-1268.

Garderen, V.D. 2006. Spatial Visualization, Visual Imagery, and Mathematical Problem Solving of Students with Varying Abilities. Dalam Journal of Learning Disabilities.No.6. Vol.XXXIX,496-506.

Geary, D.C., et al. 2000. Sex Differences in Spatial Cognition, Computational Fluency, and Arithmetical Reasoning. Dalam Journal of Experimental Child Psychology. No.4. Vol. LXXVII,337-353.

Guven, B., dan Kosa, T. 2008. The Effect of Dynamic Geometry Software on Student Mathematics Teachers' Spatial Visualization Skills. Dalam The Turkish Online Journal of Educational Technology. No.11. Vol. VII,1303-6521.

Hegarty, M. dan Kozhevnikov, M. 1999. Types of Visual-Spatial Representations and Mathematical Problem Solving. Dalam Journal of Educational Psychology. No.4. VolXCI,684-689.

NCTM. 2000. Principles and Standards for Schools Mathematics. Reston, VA: NCTM Inc.

Pohl, C.Q dan Lehmann, W. 2002. Girls' Spatial Abilities: Charting the Contributions of Experiences and Attitudes in Different Academic Groups. Dalam British Journal of Educational Psychology. Vol. LXXII, 245260.

Shadiq, F. 2004. Pemecahan Masalah, Penalaran dan Komunikasi. Yogyakarta: DEPDIKNAS. 2009. Kemahiran Matematika. Yogyakarta: DEPDIKNAS.

Sipus, Z.M dan Cizmesija. A. 2012. Spatial Ability of Students of Mathematics Education in Croatia Evaluated by the Mental Cutting Test. Dalam Annales Mathematicae et Informaticae. Vol XL, 203-216.

Steedly, K. et al. (2008). Effective Mathematics Instruction. Dalam National Dissemination Center for Children with Disabilities. No.1. Vol. III,1-11.

Suherman, E. 2001. Strategi Pembelajaran Matematika Kontemporer. Bandung: Universitas Pendidikan Indonesia.

Sumarmo, U. 2013. Berpikir dan Disposisi Matematik serta Pembelajarannya. Bandung: FMIPA UPI 
Unal, H., et al. 2009. Differences in Learning Geometry Among High and Low Spatial Ability Pre-Service Mathematics Teachers. Dalam International Journal of Mathematical Education in Science and Technology. No. 8. Vol. XL, 997-1012.

Turgut, M dan Y1lmaz, S. 2012. Relationships among Preservice Primary Mathematics Teachers' Gender, Academic Success and Spatial Ability. Dalam International Journal of Instruction. No.2. Vol.V, 5-20.

Yilmaz, H.B. 2009. On the development and measurement of spatial ability. Dalam International Electronic Journal of Elementary Education. Issue 2. Vol.I, 83-96. 